\title{
GAMBARAN MENGENAI STATUS KEBERSIHAN GIGI DAN MULUT SERTA KEMANDIRIAN TOILET TRAINING PADA ANAK TUNAGRAHITA
}

\author{
Gasik Prawestri $^{1)}$, Elis Hartati ${ }^{2)}$ \\ ${ }^{1,2}$ Universitas Diponegoro \\ Jl. Prof.H.Soedarto S.H, Tembalang, Kec. Tembalang, Kota Semarang, Jawa Tengah 50275 \\ gasikprawestri@gmail.com
}

\begin{abstract}
Abstrak
Tunagrahita merupakan salah satu jenis disabilitas yang banyak terjadi di Indonesia. Jumlah tunagrahita di Kota Semarang berdasarkan data sistem informasi manajemen warga miskin (SIMGAKIN) tahun 2012 sejumlah 667 anak. Kondisi dengan anak tunagrahita yang terjadi akan mengakibatkan kurangnya perawatan diri dalam menjaga kesehatan. Perawatan diri seperti status kebersihan gigi dan mulut serta kemandirian toilet training yang baik, dibutuhkan untuk menangani permasalahan anak tunagrahita. Tujuan penelitian ini adalah untuk mengetahui gambaran mengenai status kebersihan gigi dan mulut serta kemandirian toilet training pada anak tunagrahita. Metode penelitian yang digunakan yaitu deskriptif dengan metode kuantitatif. Teknik sampling yang digunakan yaitu total sampling sebanyak 55 responden. Pengambilan data menggunakan lembar pemeriksaan OHI-S untuk status kebersihan gigi dan mulut dan kuesioner kemandirian toilet training. Hasil penelitian menunjukkan bahwa gambaran mengenai status kebersihan gigi dan mulut anak tunagrahita berada pada kategori baik sebanyak $43.6 \%$, sedang $50.9 \%$, dan buruk 5.5\%, sedangkan kemandirian toilet training pada kategori mandiri sebanyak $21.8 \%$, kurang mandiri $50.9 \%$, dan tergantung total $27.3 \%$. Pihak sekolah diharapkan dapat memfasilitasi pelaksanaan pemeriksaan skrining gigi secara berkala 6 bulan sekali pada kebersihan gigi dan mulut serta pendampingan dalam toilet training.
\end{abstract}

Kata kunci: Tunagrahita, Status Kebersihan Gigi dan Mulut, Kemandirian Toilet Training

\begin{abstract}
Children with intellectual disabilities are one type of disabilities that frequently occur in Indonesia. The total number of children with intellectual disabilities in Semarang based on the data of poor citizens' management information system (SIMGAKIN) in 2012 is 667 children. The condition of children with intellectual disabilities that occurs will result in a lack of self-care in maintaining health. Self-care such as good dental and oral hygiene status and toilet training independence is needed to deal with the problems of children with intellectual disabilities. The purpose of this study is to describe the dental and oral hygiene status and toilet training independence in children with intellectual disabilities. The research method used is descriptive with the quantitative method. The sampling technique used is a total sampling of 55 respondents. Retrieving data using OHI-S inspection sheet for dental and oral hygiene status and independence questionnaire for toilet training. The results showed that the depiction of the dental and oral hygiene status of children with intellectual disabilities in the category of good is $43.6 \%$, medium is $50.9 \%$, and poor is $5.5 \%$, while the toilet training independence in the category of independent is $21.8 \%$, less independent is $50.9 \%$, and total dependence is 27.3 $\%$. Schools are expected to facilitate the implementation of the program to maintain and improve self-care on dental and oral hygiene and independence in toilet training.
\end{abstract}

Keywords: Intellectual Disabilities, Dental and Oral Hygiene Status, Toilet Training Independence

\section{Pendahuluan}

Anak tunagrahita atau retardasi mental merupakan anak berkebutuhan khusus yang mempunyai kemampuan intelektual di bawah rata-rata. Anak tunagrahita merupakan salah satu kriteria dengan penyandang terbanyak yang rentan terhadap paparan penyakit. Berdasarkan sistem informasi manajemen warga miskin (SIMGAKIN) Kota Semarang tahun 2015, terdapat jumlah tunagrahita pada tahun 2012 sebesar 667 anak.
Anak tunagrahita memiliki kemampuan intelektual terbatas yang perlu untuk dilatih dan adanya pembinaan diri sehingga tidak sepenuhnya menggantungkan diri pada orang lain. Menurut Palupi dkk (2017), Anak tunagrahita ringan dalam melakukan perawatan diri, mengalami keterbatasan untuk melakukan perawatan diri secara mandiri di antaranya mengenai kebersihan gigi dan mulut dan toilet training. Faktor perilaku dari anak tunagrahita yang tidak bisa mandiri, akan kesulitan untuk menyikat atau membersihan gigi dan mulut. Faktor lain didapatkan 
dari jenis makanan yang dikonsumsi anak. Adanya sisa makanan yang manis di mulut anak seperti gula yang menempel, menyebabkan munculnya bakteri untuk berkembang. (Putri dkk, 2010). Anak tunagrahita yang tidak memelihara kebersihan gigi dan mulut dengan baik, akan berisiko untuk timbulnya beberapa penyakit (Julianti, dkk 2008).

Perawatan diri anak tunagrahita yang juga mendasar dan berperan dalam kesehatan anak-anak yaitu kemandirian toilet training. Kemandirian toilet training pada anak tunagrahita meliputi anak berani untuk ke toilet tanpa ditemani orang lain, mampu melepas celana, mampu buang air kecil (BAK) dan buang air besar (BAB) mandiri, mampu menyentor kloset, mampu cebok, dan cuci tangan setelah buang air besar (BAB) dan buang air kecil (BAK) (Hidayat, 2010). Anak tunagrahita akan memiliki hambatan persepsi sensorik akan membuat anak tidak reaktif terhadap rangsang, serta tidak mengerti bagaimana cara mengguyur ketika buang air. Menurut Herlina (2013), Anak tunagrahita yang tidak bersih dalam toileting bisa terkena berbagai penyakit karena kuman masih menempel pada tubuh atau kulit. Oleh karena itu, melakukan perawatan diri dengan baik dan secara mandiri perlu untuk dilakukan. Penelitian ini bertujuan untuk mengetahui gambaran mengenai status kebersihan gigi dan mulut serta kemandirian toilet training pada anak tunagrahita.

\section{Metode}

Jenis penelitian ini adalah penelitian deskriptif kuantitatif dengan menggunakan pendekatan cross sectional study. Teknik pengambilan sampel yang digunakan adalah teknik total sampling. Jumlah sampel sebesar 55 responden. Penelitian dilaksanakan di SLB Negeri Semarang pada bulan April sampai dengan Mei 2019. Pengumpulan data dengan menggunakan lembar pemeriksaan OHI-S berdasarkan Green dan Vermilion dan kuesioner kemandirian toilet training dengan 20 item pertanyaan. Analisis data menggunakan analisis univariat. Penelitian ini disetujui oleh Komisi Etik Penelitian dengan No. 35/EC/FK UNDIP/II/2019 yang dikeluarkan tanggal 11 Februari 2019. 
Tabel 1

Distribusi Frekuensi Responden bulan April 2019

$(\mathrm{n}=55)$

\begin{tabular}{|c|c|c|c|c|}
\hline No. & Karakteristik & Frekuensi (f) & Persentase $(\%)$ & Total \\
\hline \multirow[t]{7}{*}{1.} & Kelas & & & 55 \\
\hline & a. Kelas 1 & 9 & $16.4 \%$ & \\
\hline & b. Kelas 2 & 10 & $18.2 \%$ & \\
\hline & c. Kelas 3 & 12 & $21.8 \%$ & \\
\hline & d. Kelas 4 & 8 & $14.5 \%$ & \\
\hline & e. Kelas 5 & 9 & $16.4 \%$ & \\
\hline & f. Kelas 6 & 7 & $12.7 \%$ & \\
\hline \multirow[t]{4}{*}{2.} & Usia & & & 55 \\
\hline & Kurang dari 10 Tahun & 9 & $16.4 \%$ & \\
\hline & a. $10-15$ Tahun & 40 & $72.7 \%$ & \\
\hline & b. $15-18$ Tahun & 6 & $10.9 \%$ & \\
\hline \multirow[t]{3}{*}{3.} & Jenis Kelamin & & & 55 \\
\hline & a. Laki-Laki & 33 & $60 \%$ & \\
\hline & a. Perempuan & 22 & $40 \%$ & \\
\hline
\end{tabular}

Tabel 1 menunjukkan bahwa distribusi frekuensi responden berdasarkan kelas, terbanyak berada di kelas 3 dengan jumlah $12(21.8 \%)$ responden. Distribusi frekuensi responden berdasarkan usia, mayoritas berada pada usia 10-15 tahun sebanyak $40(72.7 \%)$ responden, dan distribusi frekuensi responden berdasarkan jenis kelamin tertinggi berada pada jenis kelamin laki-laki sebanyak 60\% (33 anak).

\section{B. Gambaran status kebersihan gigi dan mulut}

Tabel 2

Distribusi frekuensi status kebersihan gigi dan mulut pada anak tunagrahita di SLB Negeri Semarang, Bulan Mei 2019

\begin{tabular}{lllc} 
& \multicolumn{2}{c}{$(\mathrm{n}=55)$} & Total \\
\hline Kategori & Frekuensi (f) & Persentase $(\%)$ & 55 \\
\hline Baik & 24 & $43.6 \%$ & \\
Sedang & 28 & $50.9 \%$ & \\
Buruk & 3 & $5.5 \%$ & \\
\hline
\end{tabular}

Tabel 2 menunjukkan bahwa distribusi frekuensi status kebersihan gigi dan mulut pada anak tunagrahita di SLB Negeri Semarang dengan kategori baik sebanyak 43.6\% (24 anak), sedang sebanyak 50.9\% (28 anak), dan buruk sebanyak 5.5\% (3 anak), sehingga dapat diketahui dapat diketahui bahwa anak tunagrahita di SLB Negeri Semarang mayoritas adalah mempunyai tingkat status kebersihan gigi dan mulut yang termasuk kategori sedang.

\section{Gambaran kemandirian toilet training pada anak tunagrahita ringan}

Tabel 3

Distribusi frekuensi karakteristik responden (Kelas, Usia, dan Jenis Kelamin) dengan kemandirian toilet training anak tunagrahita ringan

\begin{tabular}{|c|c|c|c|c|c|}
\hline Karakteristik & Kategori & Mandiri & $\begin{array}{l}\text { Kurang } \\
\text { Mandiri }\end{array}$ & $\begin{array}{l}\text { Tergantung } \\
\text { Total }\end{array}$ & Total \\
\hline Kelas & $\begin{array}{l}1 \\
2 \\
3 \\
4\end{array}$ & $\begin{array}{l}5(55.6 \%) \\
4(40.0 \%) \\
0(0 \%) \\
3(37.5 \%)\end{array}$ & $\begin{array}{l}1(11.1 \%) \\
0(0 \%) \\
7(58.3 \%) \\
5(62.5 \%)\end{array}$ & $\begin{array}{l}3(33.3 \%) \\
6(60 \%) \\
5(41.7 \%) \\
0(0 \%)\end{array}$ & 55 \\
\hline
\end{tabular}




\begin{tabular}{llllll} 
& 5 & $0(0 \%)$ & $9(100 \%)$ & $0(0 \%)$ & \\
& 6 & $0(0 \%)$ & $6(85.7 \%)$ & $1(14.3 \%)$ & \\
\hline Usia & $\begin{array}{l}\text { Kurang dari } \\
\text { 10 Tahun } \\
10-15\end{array}$ & $5(55.6 \%)$ & $0(0 \%)$ & $4(44.4 \%)$ & 55 \\
& $\begin{array}{l}\text { Tahun } \\
15-18\end{array}$ & $0(17.5 \%)$ & $23(57.5 \%)$ & $10(25 \%)$ & \\
& Tahun & & $5(83.3 \%)$ & $1(16.7 \%)$ & \\
\hline Jenis Kelamin & $\begin{array}{l}\text { Laki-Laki } \\
\text { Perempuan }\end{array}$ & $6(18.2 \%)$ & $14(42.4 \%)$ & $13(39.4 \%)$ & 55 \\
& $6(27.3 \%)$ & $14(63.6 \%)$ & $2(9.1 \%)$ & \\
\hline
\end{tabular}

Tabel 3 menunjukkan bahwa karakteristik kelas, usia, dan jenis kelamin anak tunagrahita ada pada kategori mandiri, kurang mandiri, dan tergantung total. 12 dari 55 anak tunagrahita memiliki karakteristik sebagai berikut, kelas mayoritas berada pada kelas 3 dengan kategori tidak ada yang mandiri, kurang mandiri ada 7 $(25 \%)$ responden, dan tergantung total ada 5 (33.3\%) responden. Pada karakteristik usia mayoritas berada pada usia 10-15 tahun, dengan kategori mandiri ada 7 (58.3\%) responden, kurang mandiri ada $23(82.1 \%)$, dan tergantung total ada $10(66.7 \%)$ responden. Untuk jenis kelamin mayoritas pada Laki-laki dengan kategori mandiri ada $5(45.45 \%)$ responden, kurang mandiri ada $15(51.72 \%)$ responden, dan tergantung total ada $13(86.7 \%)$ responden.

Tabel 4

Distribusi Frekuensi kemandirian toilet training pada anak tunagrahita ringan di SLB Negeri Semarang, Bulan April 2019

\begin{tabular}{lllc}
\multicolumn{3}{c}{$(\mathrm{n}=55)$} \\
\hline Kategori & Frekuensi (f) & Persentase $(\%)$ & Total \\
\hline Mandiri & 12 & $21.8 \%$ & 55 \\
Kurang Mandiri & 28 & $50.9 \%$ & \\
Tergantung Total & 15 & $27.3 \%$ & \\
\hline
\end{tabular}

Pada tabel 4 menunjukkan bahwa gambaran kemandirian toilet training dari 55 responden memiliki tingkat mandiri sebesar 21.8\% (12 anak), kurang mandiri sebesar 50.9\% (28 anak), dan tergantung total sebesar 27.3\% (15 anak), sehingga dapat diketahui bahwa anak tunagrahita di SLB Negeri Semarang mayoritas adalah mempunyai tingkat kemandirian toilet training yang termasuk kategori kurang mandiri. 
Pembahasan

\section{Karakteristik responden}

\section{A. Kelas}

Hasil penelitian mengenai karakteristik responden berdasarkan kelas menunjukkan bahwa mayoritas berada pada kelas 3 dengan jumlah 12 (21.8\%) responden. Menurut Rochyadi (2014), anak tunagrahita yang berada dikelas 3 mulai belajar untuk mengembangkan diri seperti dalam bidang akademik dan penyesuaian lingkungan. Kompetensi dasar akademik yang dimiliki pada anak tunagrahita di kelas 3 ini adalah mampu mengenal bilangan asli sampai dengan 40 dan mozaik. Penyesuaian sosial yang berkembang pada anak kelas 3 adalah mampu melakukan bina diri (merawat, mengurus, dan menolong diri sendiri) dan mengenal orang-orang terdekatnya. Namun pada perkembangannya anak masih mengalami kesulitan dalam pemeliharaan diri dalam kehidupan sehari-hari dan masih dibantu oleh orang tua. seperti cara makan, menggosok gigi, memakai baju memakai sepatu, dan lain-lain.

Perawatan diri yang baik pada status kebersihan gigi dan mulut serta kemandirian toilet training juga dipengaruhi oleh pendidikan anak. Hal tersebut didukung dengan penelitian sebelumnya yang dilakukan oleh Masni (2018), bahwa pendidikan merupakan suatu hal yang dapat mengembangkan aktualisasi diri. Pendidikan akan membuat anak tunagrahita dapat mengetahui kelebihan dan kelemahan dirinya sehingga anak akan merasa percaya diri dalam mengambil keputusan dalam hal menjaga kebersihan gigi dan mulut serta kemandirian toilet training. Anak dengan pendidikan yang semakin tinggi, cenderung akan semakin mengembangkan aktualisasi dirinya dengan baik, yang bersamaan dengan dukungan dan bantuan orang tua dalam melatih perawatan diri.

\section{B. Usia}

Hasil penelitian mengenai karakteristik responden berdasarkan usia menunjukkan bahwa mayoritas usia 10-15 tahun sebanyak 40 $(72.7 \%)$ responden. Usia antara 10-15 tahun merupakan usia yang paling banyak dari jumlah populasi pada anak tunagrahita. Hal didukung oleh penelitian sebelumnya oleh Munafiah (2013), bahwa responden penelitian didominasi oleh reponden yang berusia berkisar 10-15 tahun dengan jumlah 44 $(77.3 \%)$ responden. Usia merupakan salah satu karakteristik demografi yang diperhatikan dalam penelitian karena usia akan bepengaruh terhadap anak dalam proses melakukan perawatan diri. Pertambahan usia anak berbanding lurus dengan semakin banyaknya pengalaman yang diperoleh dari lingkungan. Perawatan diri yang dilakukan anak tunagrahita tidak jauh dari bantuan orang tua.

\section{Jenis kelamin}

Hasil penelitian menunjukkan bahwa mayoritas jenis kelamin responden adalah lakilaki sebanyak 33 (60\%). Angka kejadian anak tunagrahita lebih banyak terjadi pada anak lakilaki dibandingkan perempuan. Hal ini juga didukung oleh Hungu (2007), kejadian tunagrahita 1,5 kali lebih besar daripada perempuan. Penelitian lain menunjukkan 33 dari 65 anak tunagrahita adalah laki-laki. Jenis kelamin laki-laki memiliki kemampuan dalam melakukan kemandirian termasuk perawatan diri lebih tinggi dibandingkan anak perempuan karena anak laki-laki lebih dituntut untuk bisa mandiri dan bertanggung jawab terhadap aktivitas mereka sendiri. (Saifudin, 2011)

\section{Gambaran Status Kebersihan Gigi dan Mulut}

Hasil penelitian menunjukkan bahwa status kebersihan gigi dan mulut dalam kategori sedang mencapai angka tertinggi yaitu sebanyak 28 $(50.9 \%)$ responden. Status kebersihan gigi pada anak tunagrahita dihitung dengan menggunakan Simflied Oral Hygiene Index (OHI-S). Status kebersihan didapatkan hasil bergantung pada kondisi debris dan kalkulus anak yang hasil perhitungan diperoleh dari penjumlahan debris index (DI) dan calculus index (CI) (Sariningsih dkk, 2012). Hal ini sesuai dengan penelitian sebelumnya yang dilakukan oleh Azzahra (2014), indeks status kebersihan gigi dan mulut anak tunagrahita di SDLB C Dharma Wanita Banjarmasin termasuk dalam kategori sedang dengan skor 2,406. Hasil dalam kategori sedang ini dikarenakan anak cenderung sulit untuk menyikat giginya dengan benar dan teratur, sehingga anak membutuhkan seseorang untuk membantu dalam menjaga kebersihan gigi dan mulut, dalam hal ini yaitu orang tua.

Berbeda dengan penelitian yang dilakukan Kothari (2016), kebersihan gigi dan mulut anak tunagrahita cenderung buruk dengan skor 3,2 karena tidak menyikat gigi serta tidak ada pengawasan saat membersihan gigi. Status kebersihan gigi dan mulut yang berada dalam tingkatan sedang disebabkan karena dampak dari hasil skor OHI-S yang meliputi kondisi debris (sisa-sisa makanan) dalam mulut yang tidak mampu dibersihkan oleh anak karena kelemahan akal dan perkembangan motorik kasar yang lambat, menjadikan anak hanya bisa menyikat gigi 
secara vertikal bagian depan dan susunan geligi yang tidak beraturan, yang menjadi salah satu faktor predisposisi untuk lebih mungkin atau rentan terjadi retensi plak sehingga mempersulit upaya menghilangkan plak sehingga munculnya kalkulus.(Mawardiyanti, 2015)

Hasil penelitian yang dibagi berdasarkan usia responden tertinggi berada pada usia 10-15 tahun, mayoritas menunjukkan bahwa, status kebersihan gigi dan mulut baik sebanyak $16 \quad(40.0 \%)$ responden, sedang sebanyak $22 \quad(55.0 \%)$ responden, dan buruk sebanyak 2 (5.0\%) responden. Usia diantara 13 sampai dengan 14 tahun merupakan usia yang paling banyak. dari jumlah populasi dan memiliki kriteria kebersihan gigi dan mulut rata-rata pada kategori sedang. Hal ini juga didukung oleh penelitian Mawuntu, yang menyatakan bahwa kebersihan gigi dan mulut ratarata berada pada kategori sedang sebesar $41.52 \%$. Perawatan diri pada kebersihan gigi dan mulut mengalami sedikit penurunan saat pertambahan usia remaja, hal ini disebabkan karena semakin terbentuknya kemandirian anak dan proses dari peran orang tua dalam membantu anak tunagrahita melakukan perawatan diri. (Mawuntu, 2015)

Status kebersihan gigi dan mulut pada anak membuktikan bahwa perempuan memiliki kebersihan gigi dan mulut cukup baik dibandingkan dengan laki-laki. (Ogusile, 2010). Adanya perbedaan tingkat kebersihan gigi dan mulut pada perempuan dan laki-laki juga terlihat pada anak tunagrahita menunjukkan persentase kebersihan gigi dan mulut yaitu kategori baik pada laki-laki $18.2 \%$ dan perempuan $22.7 \%$, kategori sedang pada laki-laki $42.4 \%$ dan perempuan $68.2 \%$, dan pada kategori buruk laki-laki $39.4 \%$ dan perempuan $9.1 \%$. Hal ini juga didukung oleh penelitian Motto dkk (2017), bahwa tingkat kebersihan gigi dan mulut mayoritas berada pada kategori sedang, dengan jenis kelamin perempuan sebanyak $75 \%$.

Kebersihan gigi dan mulut anak dipengaruhi tingkat pengetahuan orang tua. Jain dkk (2009). Edukasi kesehatan gigi dan mulut serta pelayanan kesehatan gigi sangat mempengaruhi kebersihan rongga mulut anak. Mengadakan program promosi kesehatan gigi dan mulut di sekolah serta edukasi kepada orang tua dapat meningkatkan kebersihan gigi dan mulut anak. Pemberian fasilitas dan perawatan gigi dan mulut merupakan salah satu promosi kesehatan gigi dan mulut.

\section{Gambaran Kemandirian Toilet Training berdasarkan Usia pada Anak Tunagrahita}

Berdasarkan hasil penelitian dari 55 anak yang berusia 10-15 tahun sebanyak $40(72.7 \%)$ responden menunjukkan bahwa mayoritas anak berada pada kategori kurang mandiri sebanyak 23
(57.5\%). Faktor usia anak tunagrahita mempengaruhi kemandirian anak. Anak melewati tahap perkembangan dapat berjalan seiring dengan tingkat usianya. Semakin bertambah usia anak, makin tinggi tingkatan kemandirian anak tersebut. Effendi (2006). Hal ini didukung dengan penelitian Fatimah (2010), tema tentang usia yang teridentifikasi bahwa seiring bertambahnya usia akan bertambah pula kemandirian anak. Usia pada anak dengan berkebutuhan khusus seperti tunagrahita dan anak normal tidak bisa disamakan tingkat kemandiriannya, karena usia pada anak tunagrahita lebih ditekankan pada perkembangan mentalnya. Pada anak normal, latihan berkemih dan defekasi dapat dilakukan pada anak usia 18 sampai 36 bulan atau usia toddler, sedangkan pada anak berkebutuhan khusus, tidak ada rentang usia anak mampu atau belum dalam melakukan toilet training. (Berk, 2003) Anak tunagrahita yang berusia 16 tahun maka usia mentalnya setara dengan perkembangan anak normal usia 12 tahun. Kecerdasan anak tunagrahita ringan paling tinggi sama dengan anak normal berusia 12 tahun, sehingga anak tidak dapat dipaksakan belajar seperti anak seusianya. (Astati, 2001).

\section{Gambaran Kemandirian Toilet Training berdasarkan Jenis Kelamin pada Anak Tunagrahita}

Berdasarkan hasil penelitian, didapatkan bahwa Jenis kelamin anak dari 55 responden dengan kategori kurang mandiri menunjukkan bahwa $33(70.2 \%)$ responden laki-laki, mayoritas berada pada kategori kurang mandiri terdapat 14 (42.4\%) responden kurang mandiri, sedangkan jenis kelamin perempuan dari total 22 responden terdapat $14(63.6 \%)$ responden kurang mandiri dalam toilet training. Faktor Jenis kelamin juga mempengaruhi dalam kemandirian toilet training pada anak. Menurut Ramawati, anak laki-laki dituntut untuk lebih mandiri, bertanggung jawab terhadap aktivitas yang dilakukan sendiri. Jenis kelamin mempengaruhi orang tua dalam memandirikan anak tunagrahita sehingga anak perempuan cenderung untuk lebih dilindungi dari pada anak laki-laki.

\section{Gambaran Kemandirian Toilet Training pada Anak Tunagrahita}

Hasil analisa data penelitian diketahui mayoritas responden memiliki tingkat kemandirian toilet training dalam kategori kurang mandiri sebanyak $28(50.9 \%)$ responden. Kemandirian toilet training anak tunagrahita berada dalam kategori kurang mandiri disebabkan karena keterbatasan yang dimiliki anak dengan tingkat intelektual dibawah rata-rata yang akan mempengaruhi persepsi dan sensori, seperti 
ketidakmampuan anak dalam mengontrol spingter uretra (mengontrol rasa ingin defekasi dan rasa ingin berkemih) sehingga membuat anak sulit untuk melakukan toilet training. (Andriyani, 2014) Hal ini berbeda dengan penelitian sebelumnya yang dilakukan oleh Munafiah (2013), kepada 44 responden yang memberikan hasil bahwa kemandirian toilet training pada anak retardasi mental berada pada kategori mandiri dengan persentase sebesar $66 \%$. Pengetahuan dan peran orang tua menjadi faktor penting untuk menentukan keberhasilan anak dalam melakukan toilet training. Orang tua harus meluangkan waktu yang cukup untuk mendidik dan mengawasi anak agar dapat melakukan kebersihan toilet training dengan baik. Adanya pemberian latihan yang baik dan didukung oleh kesempatan merawat anak di waktu yang cukup, dapat memberikan manfaat yang baik kepada anak untuk lebih banyak berinteraksi. Penelitian ini menunjukkan adanya hubungan tingkat pengetahuan ibu dengan kemandirian toilet training pada anak retardasi mental.

Orang tua yang tidak mengajarkan anak mengenai kemandirian akan mempengaruhi terhadap keberhasilan kemandirian toilet training. Pemakaian diapers pada anak dapat menghambat kemandirian sehingga akan membuat ketergantungan total pada anak. Hal ini yang menjadi salah satu faktor anak memiliki kemandirian toilet training dalam kategori tergantung total, yang didukung dengan hasil penelitian yaitu sebesar $15(27.3 \%)$ responden. Orang tua yang tidak mengajarkan anak mengenai kemandirian toilet training secara maksimal, akan berdampak pada ketergantungan dalam bantuan orang lain. Hal ini didukung dengan penelitian yang dilakukan oleh Indanah pada anak usia toddler menunjukkan bahwa pemakaian diapers yang lama akan menghambat kemampuan toilet training pada anak tunagrahita, sehingga direkomendasikan orang tua untuk mengurangi penggunaan diapers dan melatih langsung anak dalam memandirikan toilet training (Indanah, 2014).

\section{Simpulan dan Saran}

Mayoritas reponden adalah kelas 3 dengan jumlah 12 (21.8\%), responden berusia 10-15 tahun dengan 40 $(72.7 \%)$, dan jenis kelamin laki-laki sebanyak 33 $(60 \%)$ responden. Status kebersihan gigi dan mulut pada anak tunagrahita di SLB Negeri dalam kategori sedang mencapai angka tertinggi yaitu sebanyak 28 $(50.9 \%)$ responden. Kemandirian toilet training berdasarkan usia pada anak tunagrahita, mayoritas berada pada usia 10-15 tahun sebanyak $40(72.7 \%)$ responden dengan kategori kurang mandiri sebanyak $23(57.5 \%)$ responden. Kemandirian toilet training berdasarkan jenis kelamin pada anak tunagrahita mayoritas berada pada jenis kelamin laki-laki, dengan kategori kurang mandiri sebanyak 33 (70.2\%) responden laki-laki. Kemandirian toilet training pada anak tunagrahita di SLB Negeri dalam kategori kurang mandiri mencapai angka tertinggi yaitu sebanyak 28 (50.9\%) responden. Pihak sekolah diharapkan dapat membuat dan melaksanakan program berkala untuk pelayanan konsultasi dan cek gigi rutin di UKGS (Usaha Kesehatan Gigi Siswa) 6 bulan sekali dan pendampingan toilet training pada anak, dengan bekerjasama dengan puskesmas

\section{Daftar Pustaka}

Andriyani S, Ibrahim K, Wulandari S, Cimahi A D, Keperawatan F, Padjadjaran U. (2014). Analisis Faktor-Faktor yang Berhubungan Toilet Training pada Anak Prasekolah. 2,146-53. Available from

jkp.fkep.unpad.ac.id/index.php/jkp/article/view/8 4

Asmadi. 2008. Konsep Dasar Keperawatan. Jakarta: EGC.

Astati. 2001. Persiapan Pekerjaan Penyandang Tunagrahita. Bandung: Penerbit CV. Pandawa

Azzahra N N, Wasilah S, Aspriyanto D. (2014). Indeks Kebersihan Rongga Mulut pada Anak Retardasi Mental. Dentino Jurnal Kedokteran Gigi. 2(1),79-82. Available from : http://fkg.ulm.ac.id/id/wpcontent/uploads/2016/01/Indeks-KebersihanRongga-Mulut-Pada-Anak-Retardasi-Mental.Pdf.

Berk, Laura E. 2003. Child Development, sixth edition, USA: Allyn and Bacon.

Effendi M. 2006. Pengantar Psikopedagonik Anak Berkelainan. Jakarta : Bumi Askara.

Fatimah, Enung. 2010. Psikologi Perkembangan (Psikologi Perkembangan. Peserta Didik). Bandung: CV Pustaka Setia.

Herlina. (2013) Hubungan Pola Asuh Keluarga dengan Kemandirian Perawatan Diri Anak Usia Sekolah di Kelurahan Cisalak Pasar Kecamatan Cimanggis Depok. FIK UI. Available from : lib.ui.ac.id/file?file=digital/20334363-T32623Herlina.pdf

Hidayat A A A. 2010. Pengantar Ilmu Keperawatan Anak. Jakarta:Salemba Medika.

Hungu. 2007. Demografi Kesehatan Indonesia. Jakarta: Grasindo.

Indanah, Azizah N, Handayani T. (2014) Pemakaian Diaper,S dan Efek Terhadap Kemampuan Toilet Training Pada Anak Usia Toddler.JIKK. 5(3),6168. Available from : https://ejr.stikesmuhkudus.ac.id/index.php/jikk/art icle/view/237

InfoDATIN. 2014. Penyandang Disabilitas Pada Anak [Internet]. Jakarta, 1-5 p. Available from: 
www.depkes.go.id/download.php?file=download /.../infodatin/infodatin_disabilitas.pdf0A

Jain M, Marthur A, Sawla L, Choudhary G, Kabra K, Duraiswamy P. (2009) Oral health status of mentally disabled subjects in India. J Oral Sci. 51(3), 333-40. Available from : https://www.ncbi.nlm.nih.gov/pubmed/19776499

Julianti R, Dharma M, Erdaliza, Anggia D, Fahmi F, Laila A, et al. 2008. Gigi dan Mulut. Tutorial. University of Riau: Riau.

Kothari S, Bhambal A, Saxena V, Bhambhani G, Dubey P. (2016). Impact of various sociodemographic factors on oral hygiene of mentally retarded residing in Bhopal city , Madhya Pradesh : A cross - sectional study. 3540. Available from : http://www.jiaphd.org/article.asp

Masni . (2018) Urgensi Pendidikan Dalam Mengembangkan Potensi Diri Anak. 275-86. Available from

dikdaya.unbari.ac.id/index.php/dikdaya/article/d ownload/110/104

Mawardiyanti D. (2015). Gambaran Kebersihan Gigi Dan Mulut Pada Penderita Down Syndrom SLB Patrang Jombang [Skripsi]. Universitas Jember : Fakultas Kedokteran Gigi. Available from : http://repository.unej.ac.id/bitstream/handle/123 456789/3455/Skripsi.p df?sequence $=1$

Mawuntu M M. (2015). Gambaran Status Kebersihan Mulut Siswa SD Katolik ST. Agustinus Kawangkoan. Jurnal e-GiGi(Eg) [Internet]. 3(2). Available from

https://ejournal.unsrat.ac.id/index.php/egigi/articl e/view/8763

Motto C J, Mintjelungan C N, Ticoalu S H R. (2017). Gambaran kebersihan gigi dan mulut pada siswa berkebutuhan khusus di SLB YPAC Manado. Jurnal e-GiGi (eG). 5(1). Available from : https://ejournal.unsrat.ac.id/index.php/egigi/articl e/view/15632

Munafiah, S. (2013). Hubungan Tingkat Pengetahuan Ibu Dengan Kemandirian Toilet Training Pada Anak Retardasi Mental Di SLB Negeri Surakarta. Available from : eprints.ums.ac.id/27218/15/02._Naskah_Publika si.pdf

Ogusile S, Ojo I. (2010). Oral hygiene status of adolescents in a local government area of Oyo state Nigeria. Journal of Science and Technology. p 81-85. Available from : https://www.ajol.info/index.php/just/article/view 164647

Palupi DN, Ranny R, Zamidha OA. (2017). Peran Perawat dalam Meningkatkan Kebersihan Gigi dan Mulut Anak Tunagrahita.Universitas Brawijaya.Available from http://www.poltekkesdenpasar.ac.id/keperawatangigi/
Putri MH, Herijulianti E, Nurjannah N. 2010. Ilmu Pencegahan Penyakit Jaringan Keras dan Jaringan Pendukung Gigi. Jakarta: EGC Penerbit Buku Kedokteran. 54-64; 93-95; 111-112.

Ramawati D. Faktor-faktor Berhubungan dengan Kemampuan Perawatan Diri Anak Tunagrahita di Kabupaten Banyumas. [Tesis]. Depok : FIK UI. Available from : lontar.ui.ac.id/file?file=pdf/abstrak20280451.pdf

Rochyadi E. (2014) Modul Karakteristik dan Pendidikan Anak Tunagrahita. Pengantar pendidikan luar biasa. PGSD4409/MODUL 6.

Saifudin M. (2011). Peran Keluarga dengan Kemampuan Merawat Diri Anak Retardasi Mental Sedang. Available from : https://journal.unigres.ac.id/index.php/JNC/articl e/view/28/0

Sambo CM. (2015). Toilet Training [Internet]. [cited 2018 Nov 22]. Available from: http://www.idai.or.id/artikel/klinik/pengasuhananak/toilettraining

Sariningsih E. 2012. Merawat Gigi Anak Sejak Usia Dini. Jakarta: Kompas Gramedia. 